\title{
Hormonal regulation of connexin-43 in baboon corpora lutea
}

\author{
F S Khan-Dawood, J Yang and M Y Dawood \\ Division of Reproductive Endocrinology, Department of Obstetrics, Gynecology and Reproductive Sciences, University of Texas Health Science Center, \\ Houston, Texas 77030, USA \\ (Requests for offprints should be addressed to F S Khan-Dawood, Department of Obstetrics, Gynecology and Reproductive Sciences, University of Texas \\ Medical School, 6431 Fannin, MSB 3.016, Houston, Texas 77030, USA)
}

\begin{abstract}
The synthesis and secretion of progesterone in the corpus luteum are regulated by both endocrine and paracrine/ autocrine factors which affect the steroidogenic cells. Evidence suggests that these cells communicate via cellcell junctional proteins, the connexins. Previously we have shown that connexin-43 is expressed in both human and baboon (Papio hamadryus anubis) corpora lutea, with differential expression throughout luteal development, but is not detectable in corpora albicantia. We have examined the effect of human chorionic gonadotropin (hCG), oxytocin, clomiphene citrate and the anti-progesterone onapristone on expression of connexin-43 protein in the early luteal phase 1-5 days after the mid-cycle luteinizing hormone (LH) surge (LH+1-5 days), the mid-luteal phase 6-10 days after the $\mathrm{LH}$ surge ( $\mathrm{LH}+6-10$ days), and the late luteal phase 11-15 days after the LH surge (LH+11-15 days) in corpora lutea obtained from normal adult cycling females. Connexin-43 was localized by immunohistochemistry in cultured cells from all the three stages. Western blot analysis of the treated cells indicated the presence of two bands at 43 and $45 \mathrm{kDa}$. The band at $45 \mathrm{kDa}$ was found to be phosphorylated connexin-43, indicating the presence of functional gap junctions. hCG
\end{abstract}

$(10 \mathrm{IU} / \mathrm{ml})$ stimulated the expression of connexin-43 throughout luteal development; however, maximum expression occurred in the early luteal phase with a significantly greater expression of the non-phosphorylated protein. In contrast, in the mid-luteal phase, the expression of the phosphorylated protein was predominant. Oxytocin $(200 \mathrm{mU} / \mathrm{ml})$ also stimulated connexin-43 expression throughout luteal development with similar effects on the phosphorylated and non-phosphorylated protein in the early and mid-luteal phase; however, compared with hCG, oxytocin had a greater effect on mid-luteal phase connexin-43 expression. In the presence of both hCG and oxytocin, the expression of connexin-43 was significantly higher than the control only in the late luteal phase. Both clomiphene citrate and onapristone suppressed connexin-43 expression, and concomitant addition of hCG did not counteract their effect. In the context of our previous studies, it is concluded that, together with LH/hCG and the steroid hormones, oxytocin is involved in cell-cell contact-dependent communication in the corpus luteum.

Journal of Endocrinology (1998) 157, 405-414

\section{Introduction}

Intimate cell-cell cooperation occurs between the steroidogenic cells of the corpus luteum for the synthesis of progesterone (Harrison et al. 1987, Redmer et al. 1991, Del Vecchio et al. 1994, 1995, Grazul-Bilska et al. 1994, 1996, Khan-Dawood et al. 1996a). We have proposed that contact-dependent communication involving intercellular junctions is of significant importance in these cells. We have identified gap junctions in the baboon and human corpora lutea by electron microscopy (Khan-Dawood et al. 1996b). Connexin-43, an integral component of the connexin that forms gap junctions (Beyer et al. 1990), was also immunohistologically localized in human and baboon corpora lutea (Khan-Dawood et al. 1996b). A significant observation of our studies was that the level of connexin-43 determined by Western blot analysis varied throughout the various developmental stages of the corpus luteum, with peak levels in the mid-luteal phase, when this tissue is maximally active. None was detectable in the corpus albicans (Khan-Dawood et al. 1996b).

Luteinizing hormone $(\mathrm{LH})$ plays an indispensable role in the activity of the corpus luteum (Yen 1986); however, several other factors produced by the cells of the corpus luteum may also be significantly involved in regulating progesterone synthesis (Dawood et al. 1992). Oxytocin $(\mathrm{OT})$ is one such factor that is present in the steroidogenic cells of the human (Khan-Dawood 1987a) and baboon (Khan-Dawood 1987b) corpus luteum. OT receptors are present in luteal tissue (Khan-Dawood \& Dawood 1993); OT is synthesized by luteal cells (Ivell et al. 1990) and is biologically active (Khan-Dawood et al. 1995). The levels of the peptide in the corpus luteum vary throughout the luteal phase, with maximum levels in the mid-luteal phase 
(Dawood \& Khan-Dawood 1986, Khan-Dawood et al. 1988). These observations collectively suggest that OT may be of importance in the development and demise of the corpus luteum.

To examine the role of OT in the corpus luteum further, in this study we have examined the effect of human chorionic gonadotropin (hCG), OT, clomiphene citrate (CC) and the progesterone antagonist onapristone $(\mathrm{ZK})$ on the expression of the gap junctional protein connexin-43 by baboon corpus luteum cells in culture from the early (LH surge+1-5 days), mid- (LH surge $+6-10$ days) and late (LH surge+11-15 days) luteal phases.

\section{Materials and Methods}

\section{Tissue collection}

The study was approved by the Institutional Review Board for Animal Experimentation, University of Texas Health Science Center at Houston, and was carried out in accordance with the principles and procedures described in the Guide for the Care and Use of Laboratory Animals as approved by the National Institutes of Health (NIH 80-23). Corpora lutea were obtained at laparotomy by lute-ectomy from a group of adult female cycling baboons (Papio hamadryus anubis) with well-defined menstrual cycles and weighing between 14 and $17 \mathrm{~kg}$ as previously described (Khan-Dawood et al. 1988). The menstrual cycles were monitored daily by the appearance and score of the perineal tumescence and serum progesterone following detumescence. The day of perineal detumescence was equated to the day of the LH surge. Days 1-5 after the mid-cycle LH surge were classified as the early luteal phase, days 6-10 after the LH surge were the mid-luteal phase, and days 11-15 after the LH surge were the late luteal phase. A total of nine corpora lutea, three each from the early, mid- and late luteal phases, were obtained. The tissues were immediately processed for cell culture.

\section{Materials}

Connexin-43 antibody (Dr Robert Garfield, University of Texas Medical School, Galveston, TX, USA) is a polyclonal antibody raised in rabbits against the cytoplasmic C-terminal domain consisting of the amino acid sequence from 346 to 360 of the rat and human connexin-43 sequence. This antibody was also utilized in previous studies (Khan-Dawood et al. 1996b). The secondary antibody, biotinylated goat anti-rabbit IgG, was obtained from Transduction Laboratories (Lexington, KY, USA). Sucrose, 3N-morpholinopropanesulfonic acid, phenylmethylsulfonyl fluoride (PMSF), dithiothreitol, $\mathrm{CaCl}_{2}$, fetal bovine serum (FBS), clomiphene citrate, sodium orthovanadate, $\mathrm{NaF}$ and sodium pyrophosphate were obtained from Sigma Chemical Co., St Louis, MO, USA. Trypsin containing $2 \mathrm{mM}$ EDTA, trypsin inhibitor, $\mathrm{N}$-2-hydroxyethylpiperazine- $N^{\prime}$-2-ethanesulfonic acid (HEPES), Dulbecco's modified Eagle's medium:Nutrient Mixture F-12 (DMEM/F-12) and Matrigel were obtained from Life Technologies, Gaithersburg, NJ, USA. Insulintransferrin-selenium-bovine serum albumin $\left(\mathrm{ITS}^{+}\right)$was obtained from Collaborative Biomedical Products, Bedford, MA, USA. Collagenase type IV $(132 \mathrm{U} / \mathrm{mg})$ was obtained from Worthington Biochemicals, Freehold, NJ, USA. Alkaline phosphatase MB grade $(1000 \mathrm{U} / \mathrm{ml})$ was obtained from Boehringer-Mannheim Biochemicals, Indianapolis, IN, USA. hCG and OT were gifts from Organon Inc., West Orange, NJ, USA and Sandoz, Basle, Switzerland respectively. Onapristone (ZK 98.299) was a gift from Schering AG, Berlin, Germany.

\section{Luteal cell culture}

The corpora lutea were dispersed in DMEM/F-12 containing $50 \mathrm{U} / \mathrm{ml}$ collagenase, $0.15 \mathrm{mg} / \mathrm{ml}$ DNase and $4.7 \mathrm{mg} / \mathrm{ml}$ HEPES for $2 \mathrm{~h}$ at $37^{\circ} \mathrm{C}$. After collagenase treatment, the supernatant with the dissociated cells was centrifuged at $200 \boldsymbol{g}$ for $5 \mathrm{~min}$. The cells were washed three times. The final pellet was suspended in DMEM/ F-12 containing ITS $^{+}$and $1 \%$ heat-inactivated FBS. The remaining undissociated tissue was further dispersed mechanically with a Pasteur pipet and centrifuged. Cells in the supernatants were combined, and an aliquot was counted in a hemocytometer. The viability of the cells was determined using the trypan blue-exclusion test (Tennant 1964), and $92 \pm 2 \%(n=9)$ of the cells were found to be viable.

Effect of $h C G, O T$, clomiphene citrate and onapristone on the expression of connexin-43

Luteal cells from each corpus luteum from each phase (early, mid- and late luteal phases) were cultured in triplicate for 4 days. Cells (100 000/well) were plated in 24-well culture dishes (Falcon, Oxnard, CA, USA) coated with the basement membrane, Matrigel (diluted 1:3, $40 \mu \mathrm{l} /$ well) and cultured in $1 \mathrm{ml}$ DMEM/F-12 medium containing ITS $^{+}$and $1 \%$ heat-inactivated FBS at $37^{\circ} \mathrm{C}$ in $5 \% \mathrm{CO}_{2}$ and air. The cells attached within $24 \mathrm{~h}$; the FBS-containing medium was then replaced with medium without FBS, and the cells were cultured for a further $24 \mathrm{~h}$. Cells were treated with hCG, OT, clomiphene citrate or onapristone, or hCG and OT, hCG and clomiphene citrate, or hCG and onapristone for 2 days, with medium being replaced every $24 \mathrm{~h}$. At the end of the 2 days the cells were trypsinized $(0 \cdot 01 \%$ trypsin and $2 \mathrm{mM}$ EDTA), and an aliquot was removed for protein determination (Lowry et al. 1951). The remainder were lysed in buffer (O'Farrell 1975) and processed for Western blot analysis. In initial experiments, 
the appropriate concentrations of hCG and OT to be used were determined on the basis of our previous studies (Khan-Dawood et al. 1988). Thus 10, 25 and $50 \mathrm{IU} / \mathrm{ml} \mathrm{hCG}$ and 50, 100 and $200 \mathrm{mU} / \mathrm{ml} \mathrm{OT}$ were evaluated using cells from the early luteal phase corpora lutea $(n=3)$.

\section{Western blot analysis of connexin-43}

Cultured cells were lysed in buffer (O'Farrell 1975) after trypsin treatment. The buffer contained $1 \mathrm{mM} \mathrm{MgCl}$, $0.01 \mathrm{U} / \mathrm{ml}$ aprotinin, $5 \mathrm{mM}$ PMSF and $1 \mathrm{mM} \mathrm{CaCl}_{2}$. After sonication for $20 \mathrm{~s}$, samples were boiled for $5 \mathrm{~min}$, and $10 \mu \mathrm{g}$ protein samples were electrophoresed on an SDS-12\% polyacrylamide gel. After transfer to nitrocellulose membranes (Hybond-C Super, Amersham, Arlington, IL, USA), reaction with the primary antibody at $1 \mu \mathrm{g} / \mathrm{ml}$ (a dilution of $1: 1000$ ) for $16 \mathrm{~h}$ at $4{ }^{\circ} \mathrm{C}$ and biotinylated secondary antibody $(0.5 \mu \mathrm{g} / \mathrm{ml}, 1: 2000$ dilution), the reaction products were detected using the Renaissance chemiluminescence procedure essentially as described by the manufacturer (Dupont-NEN, Boston, MA, USA). Prestained SDS-PAGE standards (Bio-Rad, Richmond, CA, USA) were run in parallel with each sample. To determine if connexin-43 was expressed in a phosphorylated form, $20 \mu \mathrm{g}$ protein from hCG- (10 IU/ $\mathrm{ml})$ and OT- $(200 \mathrm{mU} / \mathrm{ml})$ treated cells were incubated in the presence or absence of $20 \mathrm{U}$ alkaline phosphatase for $4 \mathrm{~h}$ at $37^{\circ} \mathrm{C}$ in the absence or presence of alkaline phosphatase inhibitors (1 $\mathrm{mM}$ sodium orthovanadate, $10 \mathrm{mM} \mathrm{NaF}$ and $10 \mathrm{mM}$ sodium pyrophosphate). The samples were heated at $60{ }^{\circ} \mathrm{C}$ for 5 min to inactivate the enzyme, and aliquots equivalent to $10 \mu \mathrm{g}$ protein were analyzed by Western blot analysis as described (Musil \& Goodenough 1993).

\section{Immunohistological localization of connexin-43 in cultured cells}

Luteal cells from each phase (early, mid and late) of the luteal cycle were cultured on Matrigel-coated fourchamber glass slides for 4 days. After a rinse with PBS, $\mathrm{pH}$ $7 \cdot 2$, the cells were fixed with $99 \cdot 9 \%$ methanol and incubated for $16 \mathrm{~h}$ at $4{ }^{\circ} \mathrm{C}$ with the connexin- 43 antibody at a dilution of 1:200. After several washes, the cells were treated with the secondary antibody, and the antigen was visualized using 3,3'-diaminobenzadine as the chromogen.

\section{Analysis of data}

The Western blots of three different corpora lutea from each phase were analyzed by determining band intensities at $43-45 \mathrm{kDa}$ using a PhosphorImager Series 400 (Molecular Dynamics, Sunnyvale, CA, USA). Bands at $43 \mathrm{kDa}$ and the phosphorylated band at $45 \mathrm{kDa}$ (43P kDa) were also analyzed separately. Image Quant 3.2 software was utilized. The densitometric values obtained for total connexin-43 were statistically analyzed using a one-way ANOVA to compare untreated and treated cells $(n=3)$. The levels of connexin-43 and connexin-43P were also compared both with the control untreated cells and within each treatment group. Significant differences between samples were determined using Student-Newman-Keuls test. Differences were considered to be significant at $P \leq 0 \cdot 05$.

Photomicrographs were obtained of the immunohistological slides at a magnification of $100 \times$ using an Olympus OM-T4 camera (Olympus Corporation, Woodbury, NY, USA).

\section{Results}

Expression of connexin-43 in cultured cells

After culture for 4 days, connexin- 43 was expressed in the luteal cells at all stages of luteal development examined. Positive immunoreactivity was observed as brown reaction products (Fig. 1a; positive immunoreactive material is dark grey) at the cell periphery. In the absence of the primary antibody, no immunoreactivity was observed (Fig. 1b). Preliminary experiments indicated that maximum connexin-43 expression and progesterone secretion occurred after the cells had been in culture for 4 days. Western blot analysis indicated that the protein is expressed as a doublet at all stages of luteal development with bands identifiable at 43 and $45 \mathrm{kDa}$. The band at $45 \mathrm{kDa}$ was determined to be in a phosphorylated form, since treatment with alkaline phosphatase of hCG- and OT-treated cells eliminated this band on Western blots. This band is referred to as the band at $43 \mathrm{P} \mathrm{kDa}$ or connexin-43P (Fig. 2).

Effect of increasing concentrations of hCG and OT on connexin-43 expression

In the early luteal phase cells, hCG at doses 10, 25 and $50 \mathrm{IU} / \mathrm{ml}$ increased the total expression (bands at 43 and $43 \mathrm{P} \mathrm{kDa}$ quantified together) of the protein in a dosedependent manner (Fig. $3 a$ and $b$ ). Thus at $10 \mathrm{IU} / \mathrm{ml}$, hCG increased $(P<0 \cdot 05)$ connexin-43 expression 1.9-fold and at $50 \mathrm{IU}$ by 5 -fold as compared with the control. OT also stimulated the total expression of connexin-43, with $50 \mathrm{mU} / \mathrm{ml}$ increasing its expression 2.5-fold and $200 \mathrm{mU} /$ $\mathrm{ml}$ increasing it 4-fold. A more significant observation is that, in the presence of hCG at the doses examined (10, $25,50 \mathrm{IU} / \mathrm{ml}$ ), a statistically significant increase in the non-phosphorylated band and phosphorylated band was observed, compared with non-hCG-treated cells. With $10 \mathrm{IU} / \mathrm{ml} \mathrm{hCG}$, a 3-fold increase in the nonphosphorylated band at $43 \mathrm{kDa}$ and a 2-fold increase in the 

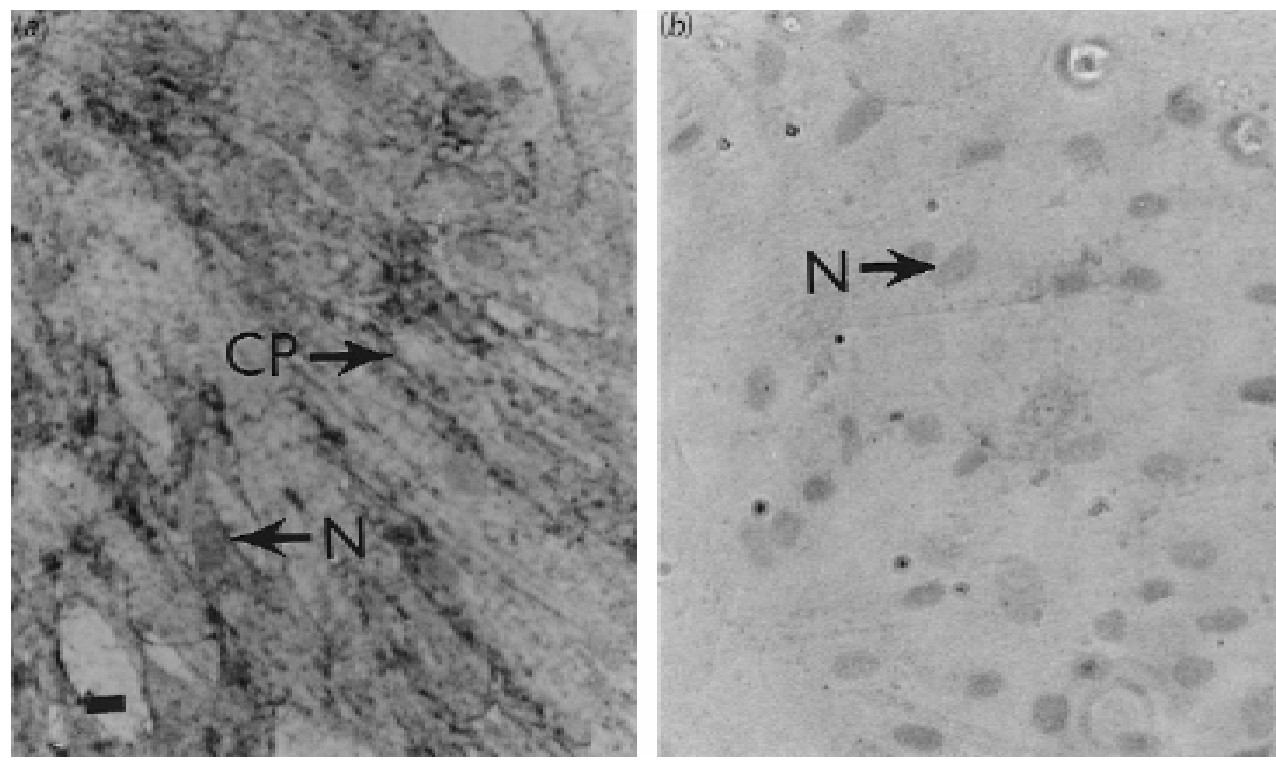

Figure 1 Immunohistological localization of connexin-43 in cultured luteal cells from the mid-luteal phase baboon corpus luteum. Cells were in culture for 4 days. Connexin- 43 is present at the cell periphery (CP) (a) and was also identified in the early and late luteal phase cells (not shown). In the absence of the primary antibody, reaction products were not observed $(b)$. Nuclei $(\mathrm{N})$ were localized with hematoxylin. Scale bar represents $20 \mu \mathrm{m}$. Magnification $\times 100$.

phosphorylated connexin-43 occurred. At $50 \mathrm{IU} / \mathrm{ml}$ hCG a 4-fold increase in both the phosphorylated and non-phosphorylated connexin-43 was observed. In the presence of OT, both connexin-43 and connexin-43P increased in equal proportions, except with $200 \mathrm{mU} / \mathrm{ml}$

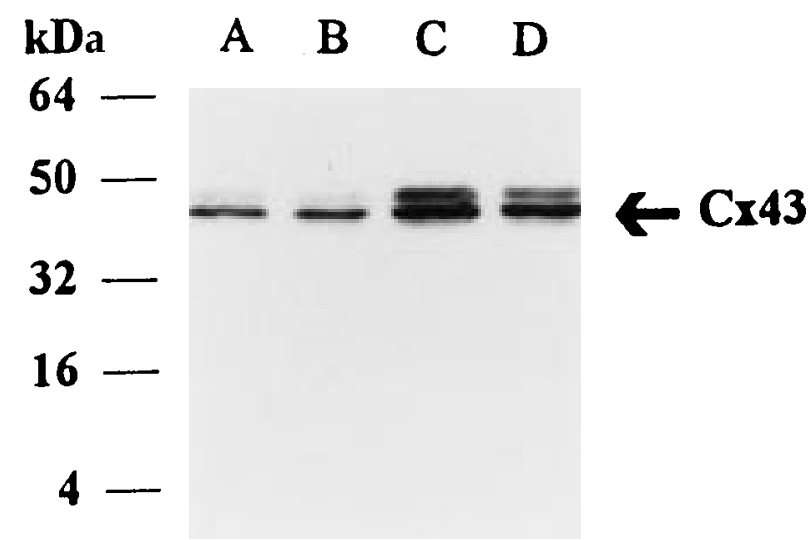

Figure 2 Representative Western blot of mid-luteal phase corpora lutea protein connexin-43 (Cx43) after treatment of cells with hCG (lanes A and C) and OT (lanes B and D). Bands in lanes C and D show protein before treatment with alkaline phosphatase $(n=3)$, and bands in lanes A and B, after treatment with alkaline phosphatase $(n=3)$. The phosphorylated band at $45 \mathrm{kDa}(43 \mathrm{P})$ is absent from the alkaline phosphatase-treated protein. A $10 \mu \mathrm{g}$ sample of cell protein was analyzed in each case.
OT, when the increase in connexin-43P was greater (4-fold) than the increase in connexin-43.

\section{Effect of $h C G$ and $O T$ on the expression of connexin-43}

In untreated cells, maximum expression of total connexin (connexin-43 and connexin-43P) was observed in the mid-luteal phase cells (Fig. 4). Densitometric analysis of the band intensities of three blots show the following distribution: early luteal phase $32 \pm 3 \%$, mid-luteal phase $42 \pm 2 \%$ and late luteal phase $26 \pm 4 \%$. The mid-luteal phase values were statistically significantly different $(P<0 \cdot 05)$. Maximum expression of connexin-43 was also observed in the mid-luteal phase in tissue homogenates, as shown in previous studies (Khan-Dawood et al. 19966).

hCG stimulated the expression of total connexin-43 in the early, mid- and late luteal phase cells, with maximum effectiveness in the early luteal phase (Figs $5 a, 6 a$ and $7 a$ ). Also, in the early luteal phase, a significantly greater expression of the non-phosphorylated connexin-43 was observed in comparison with connexin-43P. In contrast, in the mid-luteal phase, the expression of connexin-43P was significantly greater than the non-phosphorylated connexin-43. In the late luteal phase, the stimulatory effect of hCG was significantly lower than in the early and mid-luteal phase, with no significant difference between the phosphorylated and non-phosphorylated connexin-43 (Figs $5 b, 6 b$ and $7 b$ ). 
(a)

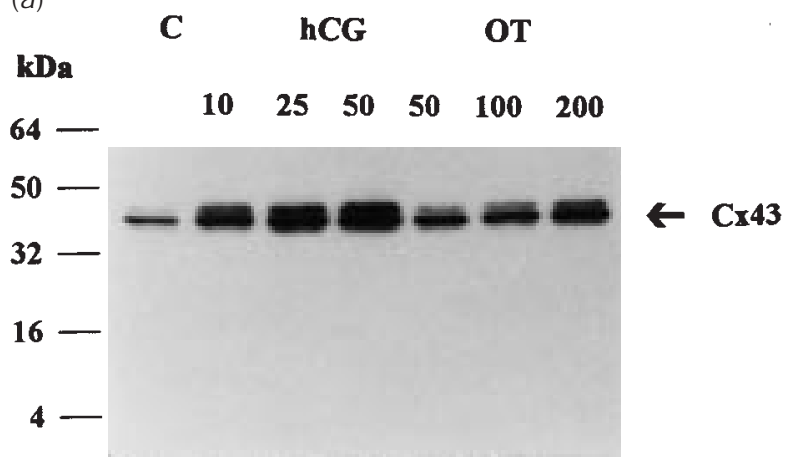

(b)

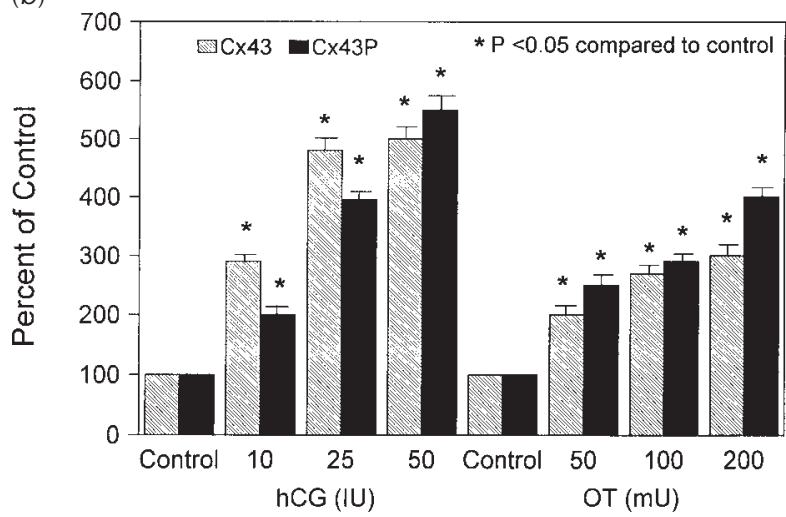

Figure 3 (a) Representative Western blot of the dose effect of hCG and OT on the expression of connexin-43 (Cx43) in cells obtained from an early luteal phase corpus luteum. Cells were cultured for 4 days. Connexin-43 is expressed as a doublet at 43 and $45 \mathrm{kDa}$. Connexin-43P is at $45 \mathrm{kDa}$. A $10 \mu \mathrm{g}$ sample of cell protein was analyzed in each case. The positions of the prestained molecular mass standards are indicated by the bars on the left. (b) Comparison of the levels of connexin-43 and connexin-43P with increasing concentrations of hCG $(10,25,50 \mathrm{IU} / \mathrm{ml})$ and OT (50, $100,200 \mathrm{mU} / \mathrm{ml}$ ). All data are compared with untreated control cells, which were designated as $100 \%$. Values are means \pm S.E.M. for three experiments. ${ }^{*} P<0.05$ compared with the control.

OT also had a stimulatory effect on the expression of total connexin-43 in the early and mid-luteal phase cells, with a greater increase in the mid-luteal phase (Figs $5 a, 6 a$ and $7 a$ ). The OT-stimulated expression of connexin-43 and connexin-43P was similar in the early and midluteal phases. Interestingly, in the late luteal phase, the expression of the non-phosphorylated connexin-43 was significantly higher than connexin-43P.

In the presence of hCG $(10 \mathrm{IU} / \mathrm{ml})$ and OT $(200 \mathrm{mU} /$ $\mathrm{ml}$ ) together, the expression of total connexin was significantly higher than the control only in the late luteal phase cells. In contrast, in the mid-luteal phase, hCG and OT treatment resulted in a $50 \%$ decrease in the total expression of connexin-43. In the early and late luteal phase cells, a significantly higher increase was observed in connexin-43 compared with connexin-43P. The expres-

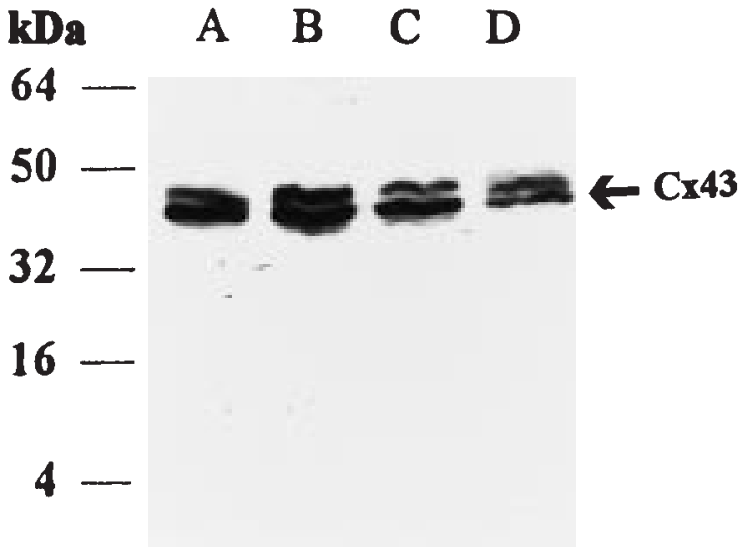

Figure 4 Representative Western blot of early luteal phase (lane A), mid-luteal phase (lane B) and late luteal phase (lane C) cells cultured for 4 days showing expression of connexin-43 (Cx43). Abundant expression in the mid-luteal phase, which was significantly $(P \leq 0.05)$ different from that in the early and late luteal phases, confirms previous in vivo data. Lane D is a cardiac tissue control. A $10 \mu \mathrm{g}$ sample of cell protein was analyzed in each case $(n=3)$.

sion of the phosphorylated form in the hCG- and OTtreated early luteal phase cells was not significantly different from the untreated cells. In the mid-luteal phase, a greater $(P<0.05)$ decrease in the non-phosphorylated connexin-43 was observed compared with connexin-43P (Figs $5 b, 6 b$ and $7 b$ ).

\section{Effect of clomiphene citrate and onapristone on connexin-43} expression in the mid-luteal phase

Both clomiphene citrate $(30 \mathrm{nmol} / \mathrm{ml})$ and onapristone $(300 \mathrm{nmol} / \mathrm{ml})$ significantly decreased the expression of total connexin-43, with the effect on the phosphorylated and non-phosphorylated forms being similar. However, when hCG was added with clomiphene citrate or onapristone, the total expression of connexin-43 was not affected, compared with the cells treated with clomiphene citrate or onapristone only. When clomiphene citrate and onapristone were combined, the expression of total connexin-43 was also not different from the untreated cells (Fig. $8 a$ and $b$ ).

\section{Discussion}

The corpus luteum, formed by the cellular components that remain in the follicle after ovulation in response to a mid-cycle surge of pituitary LH, consists of a variety of cell types, which interact closely to perform its major role of synthesizing and secreting progesterone (O'Hara et al. 1987, Brannian \& Stouffer 1991, Fritz \& Fitz 1991, Retamales et al. 1994). Two morphologically and biochemically different cells that synthesize progesterone have 
(a)

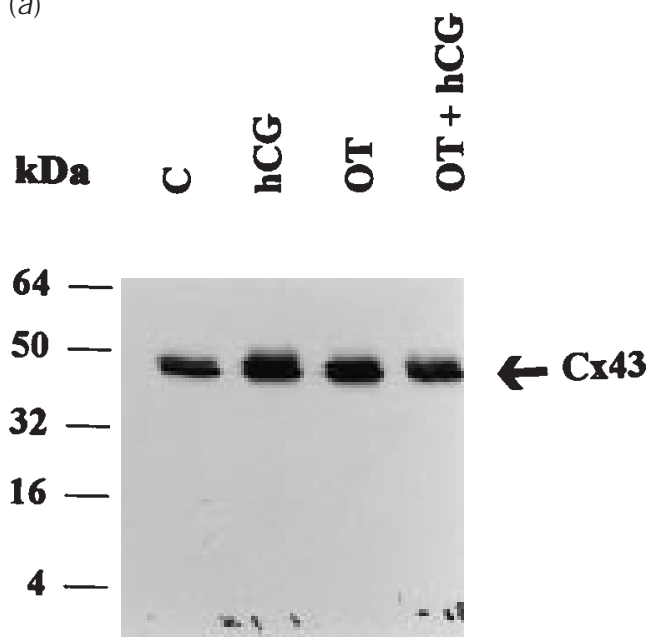

EARLY

\section{LUTEAL PHASE CL}

(b)

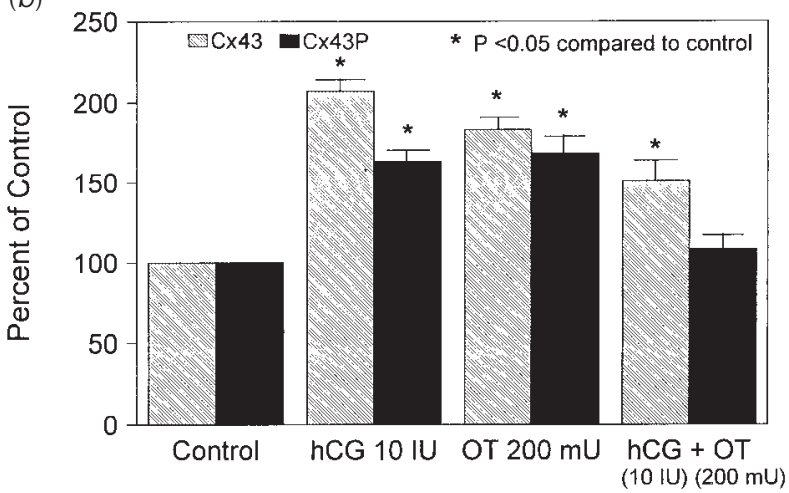

Figure 5 (a) Representative Western blot of cells from the early luteal phase corpus luteum $(\mathrm{CL})$ demonstrating the expression of connexin-43 (Cx43) in the presence of hCG $(10 \mathrm{lU} / \mathrm{ml})$, OT $(200 \mathrm{mU} / \mathrm{ml})$ or hCG+OT $(10 \mathrm{IU} / \mathrm{ml}$ and $200 \mathrm{mU} / \mathrm{ml})$, and in the absence of hCG and OT (lane C). A $10 \mu \mathrm{g}$ sample of cell protein was analyzed in each case. The positions of the prestained molecular mass standards are indicated by the bars on the left. (b) Densitometric analysis of the effect of hCG $(10 \mathrm{IU} / \mathrm{ml})$ and OT $(200 \mathrm{mU} / \mathrm{ml})$ on the expression of non-phosphorylated connexin- 43 (band at $43 \mathrm{kDa}$ ) and the phosphorylated connexin-43, connexin 43P (band at $45 \mathrm{kDa}$ ) in the early luteal phase cells. The value obtained for control cells was designated as $100 \%$. Values are means \pm S.E.M. for three experiments. ${ }^{*} P<0.05$ compared with the control.

been identified. In most species examined, one of these cells responds to $\mathrm{LH} / \mathrm{hCG}$ stimulation via $\mathrm{LH} / \mathrm{hCG}$ receptors and synthesizes progesterone; the other cell has the capacity to synthesize progesterone in the absence of an LH stimulus, although LH receptors are also present on these cells (Harrison et al. 1987, Fritz \& Fitz 1991).
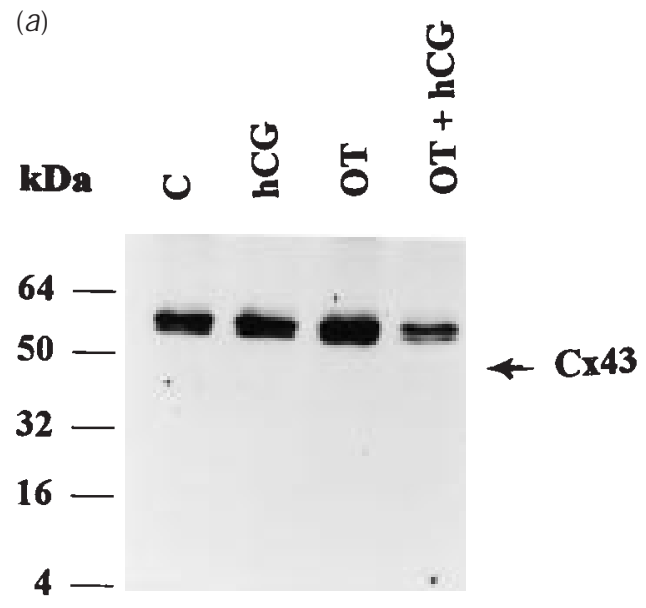

\section{MID-LUTEAL PHASE CL}

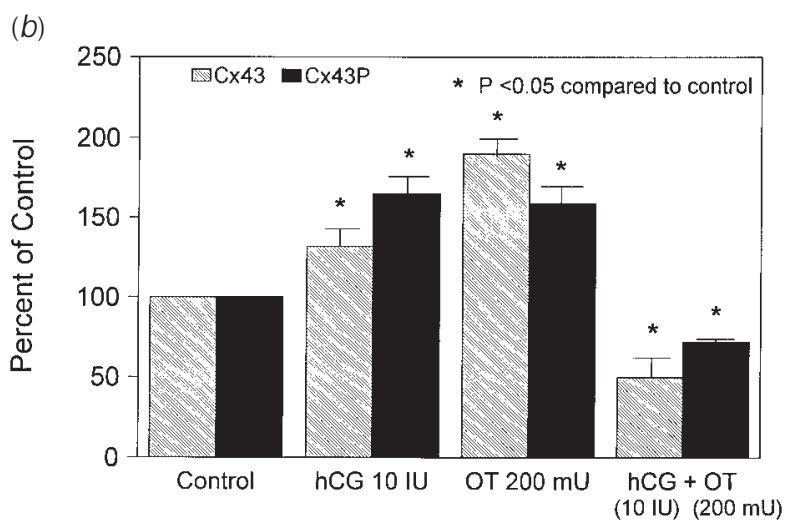

Figure 6 (a) Representative Western blot of cells from a mid-luteal phase corpus luteum $(\mathrm{CL})$ demonstrating the expression of connexin-43 (Cx43) in the presence of hCG $(10 \mathrm{lU} / \mathrm{ml})$, OT $(200 \mathrm{mU} / \mathrm{ml})$ or hCG+OT $(10 \mathrm{IU} / \mathrm{ml}$ and $200 \mathrm{mU} / \mathrm{ml})$, and in the absence of hCG and OT (lane C). A $10 \mu \mathrm{g}$ sample of protein was analyzed in each case. The positions of the prestained molecular mass standards are indicated by the bars on the left. (b) Densitometric analysis of the effect of hCG $(10 \mathrm{IU} / \mathrm{ml})$ and OT $(200 \mathrm{mU} / \mathrm{ml}$ ) on the expression of connexin-43 (band at $43 \mathrm{kDa}$ ) and connexin-43P (band at $45 \mathrm{kDa}$ ) in mid-luteal phase cells. The value obtained for control cells was designated as $100 \%$. Values are means \pm S.E.M. for three experiments. ${ }^{*} P<0.05$ compared with the control.

In the baboon corpus luteum, we have observed that the absolute concentrations of progesterone secreted by a mixed population of the two steroidogenic cell types (the 'large cell' and the 'small cell') in culture is significantly greater than when the same number of cells are cultured separately (Khan-Dawood et al. 1996a). A further observation was that the total concentration of progesterone in the medium was greater when cell-to-cell contact occurred (Khan-Dawood et al. 1996a). This evidence 
(a)

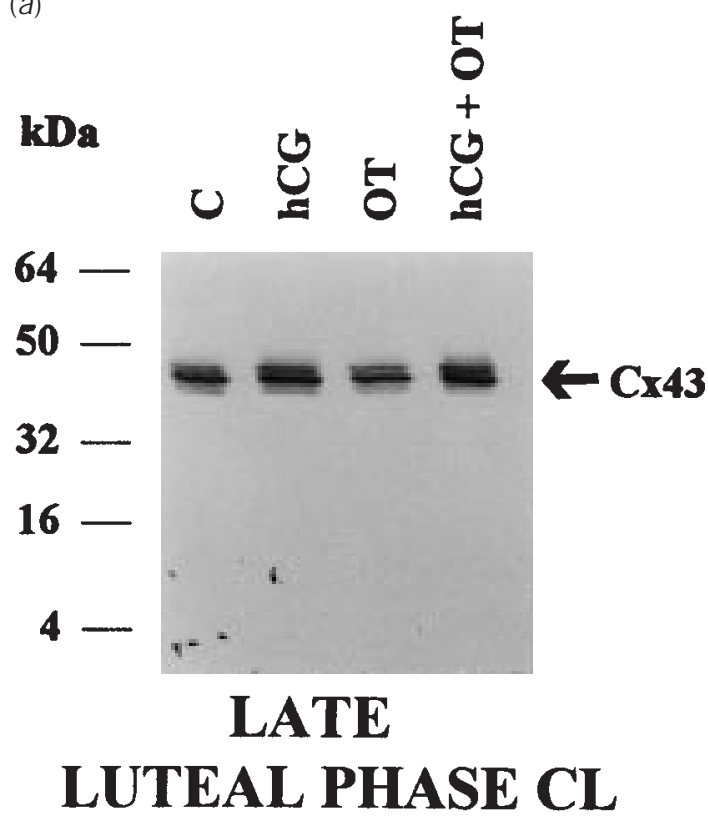

(b)

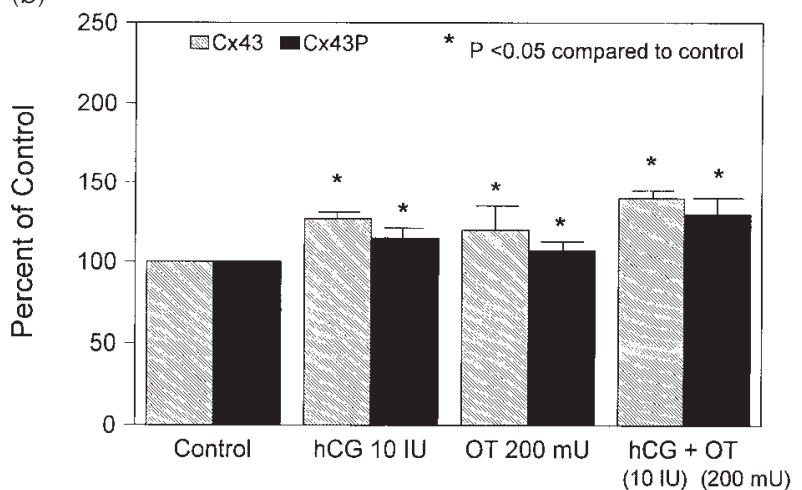

Figure 7 (a) Representative Western blot of cells from a late luteal phase corpus luteum (CL) demonstrating the expression of connexin-43 (Cx43) in the presence of hCG $(10 \mathrm{lU} / \mathrm{ml})$, OT $(200 \mathrm{mU} / \mathrm{ml})$ or hCG+OT $(10 \mathrm{lU} / \mathrm{ml}$ and $200 \mathrm{mU} / \mathrm{ml})$, and in the absence of hCG and OT (lane C). A $10 \mu$ g sample of protein was analyzed in each case. The positions of the prestained molecular mass standards are indicated by the bars on the left. (b) Densitometric analysis of the effect of hCG $(10 \mathrm{lU} / \mathrm{ml})$ and OT $(200 \mathrm{mU} / \mathrm{ml})$ on the expression of connexin-43 (band at $43 \mathrm{kDa}$ ) and connexin-43P (band at $45 \mathrm{kDa}$ ) in late luteal phase cells. Value obtained for control cells was designated as $100 \%$. Values are mean \pm S.E.M. for three experiments. ${ }^{*} P<0.05$ compared with the control.

suggests that cell-to-cell communication between the two cell types via contact-dependent interaction (Redmer et al. 1991, Grazul-Bilska et al. 1994) enhances the secretion of progesterone.

Contact-dependent communication between cells involves the formation of several junctions including gap
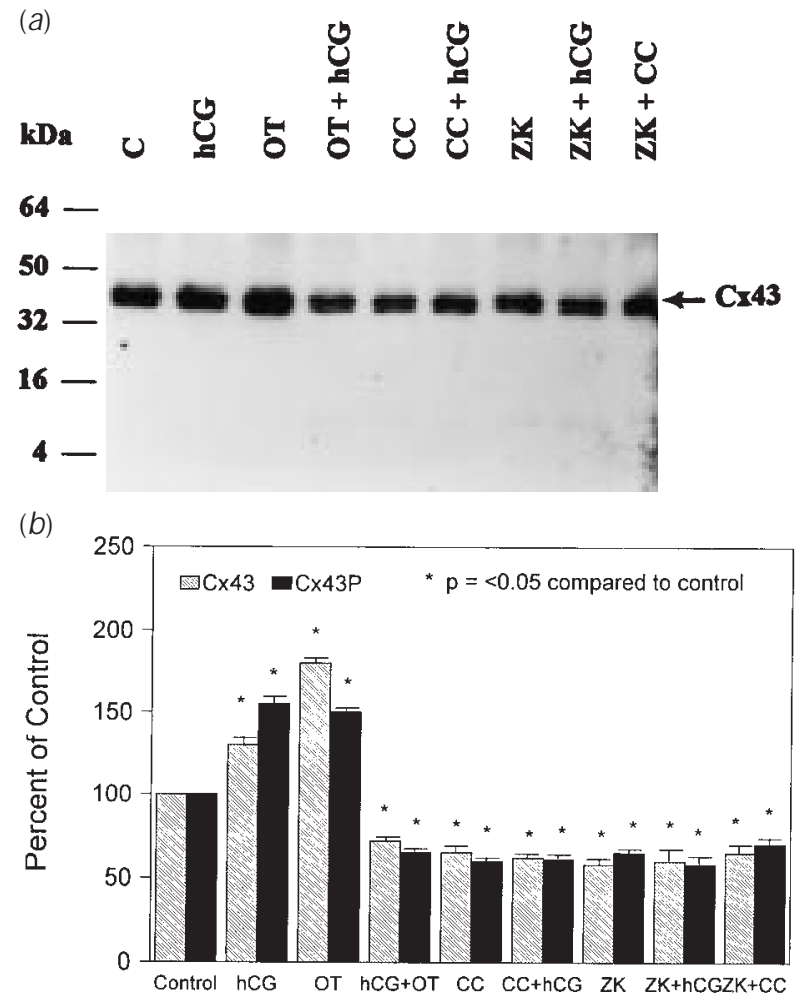

Figure 8 (a) Representative Western blot of cells from a mid-luteal phase corpus luteum demonstrating the expression of connexin-43 $(\mathrm{Cx} 43)$ in the presence of hCG $(10 \mathrm{IU} / \mathrm{ml})$, OT $(200 \mathrm{mU} / \mathrm{ml})$, hCG+OT $(10 \mathrm{lU} / \mathrm{ml}$ and $200 \mathrm{mU} / \mathrm{ml})$, clomiphene citrate (CC) $(30 \mathrm{nmol} / \mathrm{ml}), \mathrm{CC}+\mathrm{hCG}(30 \mathrm{nmol} / \mathrm{ml}+10 \mathrm{IU} / \mathrm{ml})$, onapristone $(\mathrm{ZK})$ $(300 \mathrm{nmol} / \mathrm{ml}), Z K+\mathrm{hCG}(300 \mathrm{nmol} / \mathrm{ml}+10 \mathrm{IU} / \mathrm{ml})$ and $\mathrm{ZK}+\mathrm{CC}$ $(300 \mathrm{nmol} / \mathrm{ml}+30 \mathrm{nmol} / \mathrm{ml})$. The positions of the prestained molecular mass standards are indicated by the bars on the left. A $10 \mu \mathrm{g}$ sample of protein was analyzed in each case. (b) Densitometric analysis of the effect of hCG $(10 \mathrm{lU} / \mathrm{ml})$, OT $(200 \mathrm{mU} / \mathrm{ml}), \mathrm{CC}(30 \mathrm{nmol} / \mathrm{ml})$ and $\mathrm{ZK}(300 \mathrm{nmol} / \mathrm{ml})$ on the expression of connexin-43 (band at $43 \mathrm{kDa}$ ) and connexin-43 P (band at $45 \mathrm{kDa}$ ). Value obtained for control cells was designated as $100 \%$. Values are mean \pm S.E.M. for three experiments. ${ }^{\star} P \leq 0.05$ compared with the control.

junctions, tight junctions and adherent junctions (Farquhar \& Palade 1963). Gap junctions form transmembrane channels between cells linking the cytoplasm of adjacent cells and through which low molecular mass molecules including second messengers are able to pass (Gilula et al. 1972, Loewenstein 1981, Elgang et al. 1995). Gap junctions have been identified in corpora lutea of several species by electron microscopy (Adams \& Hertig 1969, Abel et al. 1975, Albertini \& Anderson 1975, McClellan et al. 1975, Crisp \& Dessouky 1980, O'Shea et al. 1990), including the baboon (Khan-Dawood et al. 1996b). These junctions consist of a family of homologous proteins, the connexins, which are components of the hexameric connexin. One of these proteins, connexin-43, is present in 
ovine, bovine, baboon and human corpora lutea (GrazulBilska et al. 1994, Khan-Dawood et al. 1996b).

Our previous studies have shown that connexin-43 is expressed in both human and baboon corpora lutea, with abundant expression in the mid-luteal phase but undetectable levels in corpora albicantia in vivo, suggesting that the protein may be hormonally regulated (Khan-Dawood et al. 1996b). The present study confirms these observations when luteal cells from the early, mid- and late luteal phases were cultured in vitro. The presence of gap junctions and the associated protein connexin-43 in the corpus luteum suggests that the cells in this tissue are metabolically linked and are capable of cross-communication. The differential expression throughout luteal development further suggests that cell-cell interaction may be regulated (Nnamani et al. 1994). Using functional assays involving fluorescence recovery after photobleaching and laser cytometry or after passage of fluorescent Lucifer Yellow after microinjection of luteal cells, it has been shown that luteotrophic/ luteolytic hormones and cAMP modulate cell-cell interaction via gap junctions in bovine and ovine corpora lutea (Redmer et al. 1991, Grazul-Bilska et al. 1994). LH increased the rate of interaction between small and large, and small and small luteal cells but not between large and large cells. Prostaglandin $\mathrm{F}_{2 \alpha}\left(\mathrm{PGF}_{2 \alpha}\right)$ stimulated the rate of dye transfer between small and large bovine cells and between ovine large and large cells; however, it decreased the rate of dye transfer between ovine small luteal cells. $\mathrm{PGF}_{2 \alpha}$ also counteracted the stimulatory effect of LH on interaction between ovine large and small cells (Redmer et al. 1991, Grazul-Bilska et al. 1994, 1996).

The formation of functional gap junctions requires several stages, and for cells to become communicationcompetent, phosphorylation of the connexins is necessary (Stagg \& Fletcher 1990, Beyer 1993). In the rat ovarian follicle, the process of connexin-43 phosphorylation is regulated by the gonadotropins. Thus LH, forskolin and gonadotropin-releasing hormone agonist stimulated both the phosphorylation and dephosphorylation of connexin43 , but the effect of these factors was dependent on the time of exposure of the cells to these factors (Granot \& Dekel 1994).

In the baboon and human corpus luteum we have shown that connexin-43 is present as two bands at 43 and $45 \mathrm{kDa}$ (Khan-Dawood et al. 1996b). The present study demonstrates that the band at $45 \mathrm{kDa}$ is a phosphorylated protein. Both hCG and OT had modulatory effects on the phosphorylation of connexin-43 in the baboon luteal cells in culture. The effect was dependent on the stage of luteal development. Abundant expression of the phosphorylated protein occurred in the presence of both hCG and OT in the mid-luteal phase cells. This suggests that the corpus luteum cells achieve maximum communication competency with a probable increase in the rate of communication at a time when large quantities of progesterone synthesis occurs. The absence of connexin-43 from the corpus albicans, which synthesizes little progesterone, supports the contention that gap junction communication is necessary in luteal cells for progesterone synthesis. Loss of communication competency may be the cause of luteolysis. In support of these observations, $\mathrm{LH}$, dibutyryl cAMP and forskolin effectively increased the rate of gap junctional intracellular communication between cells in the mid-luteal phase of the bovine luteal cycle (GrazulBilska et al. 1996) relative to the early and late luteal phase.

In electrically excitable tissue, gap junction function and connexin-43 expression is regulated by OT (Garfield et al. 1990). The direct effect of OT on progesterone synthesis in the corpus luteum has been extensively investigated with no resulting definitive data (Khan-Dawood 1997). The present study suggests that OT may be involved in the expression and phosphorylation of the gap junctional protein in the corpus luteum. Tissue concentrations of OT and OT receptors have been determined to be significantly higher in the mid-luteal phase of the baboon and human corpus luteum (Dawood \& Khan-Dawood 1986, Khan-Dawood 1988, Khan-Dawood \& Dawood 1993), and a significantly higher stimulatory effect of OT on mid-luteal phase cell connexin-43 expression has been observed in the present studies. Collectively, this suggests that OT may modulate contact-dependent cell-cell communication by stimulating connexin-43 expression.

In contrast with the effect of hCG and OT, both clomiphene citrate, which has anti-estrogen properties (Clark \& Markaverich 1982), and onapristone, a progesterone receptor antagonist (Elger et al. 1986), decreased the expression of connexin-43 (phosphorylated and non-phosphorylated forms) in the baboon luteal cells. Co-treatment with hCG did not alter the effect. Evidence suggests that estrogen and progesterone regulate the presence of gap junctions (Garfield et al. 1990), estradiol stimulates the transcription of connexin-43 (Lye et al. 1993, Petrocelli \& Lye 1993), while progesterone alone or in combination with estradiol suppresses the expression of connexin mRNA (Grummer et al. 1994) in the myometrium and endometrium respectively. The effect of clomiphene citrate is consistent with its anti-estrogen effects. In contrast, the effect of onapristone in suppressing connexin-43 in the corpus luteum is not similar to that observed in other tissues. Only progesterone receptors are present in human (Iwai et al. 1990), rhesus monkey (Hild-Petito et al. 1988) and baboon (Khan-Dawood et al. 1993) corpora lutea, and steroidal regulation of luteal function is suggested (Stouffer \& Duffy 1995). However, both estrogen (Yu et al. 1994) and progesterone response elements in the connexin-43 gene are recognized (Lye 1993, Yu et al. 1994), suggesting direct interaction.

In summary, the present findings further support our previous data (Khan-Dawood et al. 1996a, b) and indicate that the expression of connexin-43 in the primate corpus luteum is regulated by both endocrine (LH/hCG) and paracrine/autocrine (OT, estradiol and progesterone) 
factors. These factors not only regulate connexin-43 expression but also modulate the phosphorylation of the protein, rendering it active, with differential effects on phosphorylation during luteal development. The presence of the phosphorylated protein suggests communicationcompetent steroidogenic cells, and therefore it is probable that the LH/hCG-responsive cells may communicate with the LH/hCG-non-responsive cells via gap junctions in the overall synthesis and secretion of progesterone in the corpus luteum.

\section{Acknowledgements}

We are grateful to Dr Robert Garfield (University of Texas Medical School, Galveston) for the supply of antibody to connexin-43, to Organon Inc., West Orange, NJ, USA for hCG, to Sandoz Pharmaceuticals, Basle, Switzerland, for OT, and to Schering AG, Berlin, Germany, for onapristone. The typing expertise of Mrs Mary Carson is gratefully acknowledged.

\section{References}

Abel JH, McClellan MC, Verhage HG \& Niswender GD 1975 Subcellular compartmentalization of the luteal cells in the ovary of the dog. Cell Tissue Research 158 461-480.

Adams EC \& Hertig AR 1969 Studies on the human corpus luteum. I. Observations on the ultrastructure of development and regression of the luteal cells during the menstrual cycle. Journal of Cell Biology 41 696-715.

Albertini DF \& Anderson E 1975 Structural modifications of lutein cell gap junctions during pregnancy in the rat and the mouse. Anatomical Record 181 171-194.

Beyer EC 1993 Gap junctions. International Review of Cytology 137C $1-37$.

Beyer EC, Paul DL \& Goodenough DA 1990 Connexin family of gap junctions. Journal of Molecular Biology 116 187-194.

Brannian JD \& Stouffer RL 1991 Cellular approaches to understanding the function and regulation of the primate corpus luteum. Seminars in Reproductive Endocrinology 9 341-351.

Clark TH \& Markaverich BM 1982 The agonistic-antagonistic properties of clomiphene: a review. Pharmacological Therapy $\mathbf{1 5}$ $467-519$.

Crisp TM \& Dessouky DA 1980 Fine structure of the primate corpus luteum. In Biology of the Ovary, pp 150-161. Eds PM Motta \& ESE Hafez. Boston: Martinus Nijhoff.

Dawood MY \& Khan-Dawood FS 1986 Human ovarian oxytocin: its source and relationship to steroid hormones. American Journal of Obstetrics and Gynecology 154 756-763.

Dawood MY, Nappi C, Gargiulo AR \& Montemagno U 1992 Progesterone secretion by the human corpus luteum: mechanisms of control. In Hormones in Gynecological Endocrinology, pp 547-565. Eds AR Genazzani \& F Petraglia. Lancaster, UK: The Parthenon Publishing Group.

Del Vecchio RP, Thibodeaux JK, Randel RD \& Hansel W 1994 Interactions between large and small bovine luteal cells in a sequential perifusion co-culture system. Journal of Animal Science 72 963-968.

Del Vecchio RP, Thibodeaux JK \& Hansel W 1995 Contactassociated interactions between large and small bovine luteal cells during the oestrous cycle. Domestic Animal Endocrinology 12 25-33.
Elgang C, Eckert R, Lichtenberg-Frate H, Butterweck A, Traub O, Klein RA, Hulser DF \& Willecke K 1995 Specific permeability and selective formation of gap junction channels in connexintransfected Hela cells. Journal of Cell Biology 129 805-817.

Elger W, Beier KS \& Chwaliszk 1986 Studies on the mechanism of action of progesterone antagonists. Journal of Steroid Biochemistry 25 835-845.

Farquhar MG \& Palade GE 1963 Junctional complexes in various epithelia. Journal of Cell Biology 17 375-412.

Fritz MA \& Fitz TA 1991 The functional microscopic anatomy of the corpus luteum: the small cell large cell controversy. Clinical Obstetrics and Gynecology 34 144-156.

Garfield RE, Tabb T \& Thilander G 1990 Intercellular coupling and modulation of uterine contractility. In Uterine Contractility: Mechanisms of Control: Serono Symposia, Norwell, pp 21-40. Ed RE Garfield.

Gilula NB, Reeves OR \& Steinbach A 1972 Metabolic coupling, ionic coupling, and cell contacts. Nature 235 262-265.

Granot I \& Dekel N 1994 Phosphorylation and expression of connexin-43 ovarian gap junction protein are regulated by luteinizing hormone. Journal of Biological Chemistry 269 30502-30509.

Grazul-Bilska AT, Reynolds LP, Jablonka-Shariff A \& Redmer DA 1994 Cellular interactions in luteal tissues: role of gap junctions. Assisted Reproductive Technology/Andrology 6 264-286.

Grazul-Bilska AT, Reynolds LP, Kirsch JD \& Redmer DA 1996 Gap junctional intercellular communication of bovine luteal cells from several stages of the estrous cycle: effects of cyclic adenosine $3^{\prime}$ 5'-monophosphate. Biology of Reproduction 54 538-545.

Grummer R, Chwalisz K, Mulholland J, Traub O \& Winterhager E 1994 Regulation of connexin 26 and connexin 43 expression in rat endometrium by ovarian steroid hormones. Biology of Reproduction 51 1109-1116.

Harrison LH, Kenny N \& Niswender GD 1987 Progesterone production, LH receptors, and oxytocin secretion by ovine luteal cell types on days 6,10 and 15 of the oestrus cycle and day 25 of pregnancy. Journal of Reproduction and Fertility 79 539-548.

Hild-Petito S, Stouffer RL \& Brenner RM 1988 Immunocytochemical localization of estradiol and progesterone receptors in the monkey ovary throughout the menstrual cycle. Endocrinology 123 2896-2905.

Ivell R, Furuya K, Brackman B, Dawood MY \& Khan-Dawood FS 1990 Expression of the oxytocin and vasopressin genes in human and baboon gonadal tissues. Endocrinology 127 1990-1995.

Iwai T, Nanbu Y, Iwai M, Taii S, Fujii S \& Mori T 1990 Immunohistochemical localization of oestrogen receptors and progesterone receptors in the human ovary throughout the menstrual cycle. Virchows Archiv. A, Pathological Anatomy and Histopathology 417 369-375.

Khan-Dawood FS 1987a Immunocytochemical localization of oxytocin and neurophysin in human corpora lutea. American Journal of Anatomy 179 18-24.

Khan-Dawood FS $1987 b$ Oxytocin in baboon (Papio anubis) corpus luteum. Biology of Reproduction 37 659-664.

Khan-Dawood FS 1997 The role of oxytocin in cell-to-cell communication in the corpus luteum. Endocrinologist 7 160-166.

Khan-Dawood FS \& Dawood MY 1993 Baboon corpus luteum: presence of oxytocin receptors. Biology of Reproduction 49 262-266.

Khan-Dawood FS, Huang J-C \& Dawood MY 1988 Baboon corpus luteum oxytocin: an intragonadal peptide modulator of luteal function. American Journal of Obstetrics and Gynecology 158 882-891.

Khan-Dawood FS, Dawood MY \& Satyaswaroop PG 1993 Baboon corpus luteum: immunohistochemical localization of progesterone receptors. In Program of the Society for Gynecologic Investigation, 40th Annual Meeting, Toronto, Ontario, Canada, abstract no. 348.

Khan-Dawood FS, Yang J, Anwer K \& Dawood MY 1995 Bioactive oxytocin in human and baboon corpora lutea. Journal of Endocrinology 147 525-532. 
Khan-Dawood FS, Yang J \& Dawood MY 1996a Potential role of oxytocin in cell to cell communication in the corpus luteum. In Proceedings of the Hanseatic Endocrine Conference. Oxytocin: Cellular and Molecular Approaches in Medicine and Research.

Khan-Dawood FS, Yang J \& Dawood MY 19966 Expression of gap junction protein connexin-43 in the human and baboon corpus luteum. Journal of Clinical Endocrinology and Metabolism 81 835-842.

Loewenstein WR 1981 Junctional intercellular communication; the cell-to-cell membrane channel. Physiology Review 61 829-913.

Lowry OH, Rosebrough NJ, Farr AL \& Randall RJ 1951 Protein measurement with the folin-phenol reagent. Journal of Biological Chemistry 193 265-275.

Lye S 1993 Molecular regulation of myometrial activation during labor. In Program of the Society for Gynecologic Investigation, 40th Annual Meeting, Toronto, Ontario, Canada, abstract no. 23.

Lye WJ, Nicholson BJ, Mascarenhas M, MacKenzie L \& Petrocelli T 1993 Increased expression of connexin-43 in the rat myometrium during labor is associated with an increase in the plasma estrogen:progesterone ratio. Endocrinology 132 2380-2386.

McClellan MC, Diekman MA, Abel JH \& Niswender GD 1975 Luteinizing hormone, progesterone, and the morphological development of normal and superovulated corpora lutea in sheep. Cell Tissue Research 164 291-307.

Musil LS \& Goodenough DA 1993 Multiunit assembly of an integral plasma membrane channel protein, gap junction connexin 43, occurs after exit from the ER. Cell 74 1065-1077.

Nnamani C, Godwin A, Ducsay CA, Longo LD \& Fletcher WH 1994 Regulation of cell-cell communication mediated by connexin 43 in rabbit myometrial cells. Biology of Reproduction 50 377-389.

O'Farrell PH 1975 High resolution two-dimensional electrophoresis of proteins. Journal of Biological Chemistry 250 4007-4021.

O’Hara, Mori T, Taii S, Ban C \& Narimoto K 1987 Functional differentiation in steroidogenesis of two types of luteal cells isolated from mature human corpora lutea of the menstrual cycle. Journal of Clinical Endocrinology and Metabolism 65 1192-1200.

O’Shea JD, Rodgers RJ, McCoy K \& D’Occhio MJ 1990 Ultrastructural cytology of the cyclic corpus luteum of the cow. Acta Anatomica 138 154-165.

Petrocelli T \& Lye SJ 1993 Regulation of transcripts encoding the myometrial gap junction protein, connexin-43, by estrogen and progesterone. Endocrinology 133 284-290.

Redmer DA, Grazul-Bilska AT \& Reynolds LP 1991 Contactdependent intercellular communication of bovine luteal cells in culture. Endocrinology 129 2757-2766.

Retamales I, Carrasco I, Tronscoso JL, Heras JL, Devoto L \& Vega M 1994 Morpho-functional study of human luteal cell subpopulations. Human Reproduction 9 591-596.

Stagg RB \& Fletcher WH 1990 The hormone-induced regulation of contact-dependent cell-cell communication by phosphorylation. Endocrine Reviews 11 302-325.

Stouffer RL \& Duffy DM 1995 Receptors for sex steroids in the primate corpus luteum: new insights into gonadotropin and steroid action. Trends in Endocrinology and Metabolism 6 83-89.

Tennant JR 1964 Evaluation of the trypan blue technique for the determination of cell viability. Transplantation 2 685-689.

Yen SSC 1986 The human menstrual cycle. In Reproductive Endocrinology, pp 12-34. Eds SSC Yen \& R Jaffe. New York: Saunders.

Yu W, Dahl G \& Werner R 1994 The connexin-43 gene is responsive to oestrogen. Proceedings of the Royal Society. Series B: Biological Sciences 255 125-132.

Received 7 August 1997

Revised manuscript received 5 January 1998 Accepted 16 January 1998 